\title{
PENINGKATAN PENGETAHUAN TENTANG HIGIENE DAN SANITASI SERTA IMPLEMENTASINYA PADA PEDAGANG KULINER KAKI LIMA, PADA PUSAT KULINER DI KELURAHAN PUNIA KOTA MATARAM
}

\author{
Taufik CHaidir ${ }^{1}$, Ida Ayu Putri $S^{2}$, Gst Ayu Arini ${ }^{3}$, Baiq Ismiwati ${ }^{4}$ \\ Fakultas Ekonomi dan Bisnis Universitas Mataram
}

taufiqch.feunram@gmail.com

\begin{abstract}
ABSTRAK
Salah satu kebutuhan primer manusia adalah makan karenanya setiap orang harus dapat memenuhinya dengan baik artinya makan tidak hanya harus cukup, tetapi juga yang terpenting adalah harus dapat memberikan asupan gizi dan juga harus higiene serta pengolahan harus dengan memperhatikan sanitasi. Tujuan dari pengabdian pada masyarakat ini adalah untuk meningkatkan pengetahuan pedagang kuliner terkait dengan higiene dan sanitasi dalam proses produksi makanan dan minuman dan pedagang dapat mengimplementasikan pengetahuan sehingga produksi yang dihasilkan dapat memenuhi Undang- Undang No 32 tentang kesehatan. Metode pelaksanaan pengabdian masyarakat yang digunakan adalah pertama mengobservasi sasaran target terkait dengan proses produksi dalam menghasilkan kuliner, kedua menyampaikan materi, kemudian dilanjutkan dengan diskusi serta pembentukkan tim kelompok /petugas yang akan melakukan monitoring dan evaluasi terhadap implementasi prinsip higine dan sanitasi dalam proses produksi yang dilakukan oleh pedagang. Hasil pengabdian menunjukkan pertama, peserta tidak mengetahui apa yang dimaksud dengan higiene dan sanitasi serta pengaruhnya terhadap produk yang dihasilkan. Hal ini terlihat dari proses produksi yang dilakukan dilantai, pembuangan air limbah masih dengan saluran terbuka, penyimpanan bahan makanan yang masih bercampur antara bahan makanan dan makanan jadi. Kedua, pada saat produk yang dijajakan kepada pembeli belum memenuhi standar penjualan makanan dan minuman, hal ini terihat dari masih banyaknya pedagang tidak menutup makanan dan minuman dengan
\end{abstract}


baik disamping itu pengambilan makanan tidak menggunakan alat tertentu seperti sendok.

Kata Kunci: Higine dan sanitasi, produk pengolahan makanan, kesejahteraan

\section{ABSTRACT}

One of the primary human needs is food, therefore everyone must be able to fulfill it properly, meaning that food must not only be sufficient, but also the most important thing is to be able to provide nutritional intake and also must be hygienic and processing must pay attention to sanitation. The purpose of this community service is to increase the knowledge of culinary traders related to hygiene and sanitation in the food and beverage production process and traders can implement knowledge so that the resulting production can meet Law No. 32 on health. The method of implementing community service used is firstly observing targets related to the production process in producing culinary delights, secondly delivering the material, then continuing with discussions and forming a group team/officer who will monitor and evaluate the implementation of hygiene and sanitation principles in the production process carried out. by the merchant. The results of the service show that first, participants do not know what is meant by hygiene and sanitation and their effect on the products produced. This can be seen from the production process carried out on the floor, waste water disposal is still in an open channel, food storage is still mixed between food ingredients and finished food. Second, when the products sold to buyers do not meet the standards for selling food and beverages, this can be seen from the number of traders who do not cover food and drinks properly. Besides that, taking food does not use certain tools such as spoons. Keywords: Hygiene and sanitation, food processing products, welfare

\section{PENDAHULUAN}

Salah satu kebutuhan primer manusia adalah makan karenanya setiap orang harus dapat memenuhinya dengan baik artinya makan tidak hanya harus cukup, tetapi juga yang terpenting adalah harus dapat memberikan asupan gizi dan juga harus higiene serta pengolahan harus dengan memperhatikan sanitasi. Menurut Anwar (1990) Makanan 


\section{Jurnal ABDIMAS INDEPENDEN}

Vol. 2, No. 2, November 2021

merupakan suatu hal yang sangat penting didalam kehidupan manusia, dimana makanan berfungsi memberikan tenaga atau energi panas pada tubuh, membangun jaringan-jaringan tubuh yang baru, pengatur dan pelindung tubuh terhadap penyakit, serta sebagai sumber bahan pengganti sel-sel tua yang usang dimakan usia. Makanan yang menarik, nikmat dan tinggi gizinya, tidak akan berarti sama sekali jika tidak aman untuk dikonsumsi. Hal ini disebabkan karena bila tidak mempertimbangkan hal hal tersebut maka seseorang yang walaupun sudah makan tetapi dapat menjadi tidak sehat, sehingga dapat menyebabkan kualitas sumberdaya manusia menurun yang berdampak pada Indeks pembangunan manusia rendah dan akan berujung pada tingkat kesejahteraan masyarakat menurun dan kinerja pembangunan daerah atau negara akan menjadi buruk .

Persoalan makan menjadi penting untuk diperhatikan mengingat semakin banyak rumah tangga yang tidak dapat menyiapkan makanan sendiri yang disebakan oleh karena kesibukkan masing- masing rumah tangga yang harus bekerja untuk dapat menghidupi rumah tangganya, rumah tangga yang menganggap membeli makanan lebih murah dari pada memasak sendiri sehingga untuk memenuhi makannya mereka membeli makanan yang telah diolah. Membeli makanan dianggap paling mudah untuk memenuhi kebutuhan primer ini karena tersedia hampir disetiap tempat baik pada restaurant, café maupun pedagang kaki lima. Bagi rumah tangga yang cukup mampu, persoalan dalam pembelian makanan tidaklah sulit mereka dapat memilih membeli makanan pada tempat - tempat yang menjual makanan dengan gizi yang baik, higiene dan sanitasi yang memadai tetapi bagi rumah tangga dengan pendapatan yang tidak terlalu besar tidak banyak punya pilihan untuk membeli makanan, biasanya pembelian makanan dilakukan pada pedagang kaki lima yang menjual kuliner yang gizi, higine dan sanitasinya dipertanyakan. Menurut Yuyun (2008) Yang 
dimaksud dengan Kuliner adalah hasil olahan yang berupa masakan ,masakan tersebut berupa lauk-pauk, makanan (penganan), dan minuman.

Salah satu pusat kuliner yang merupakan kelompok pedagang kaki lima di Kota Mataram terletak di kelurahan Punia. Pada tahun 2018 jumlah penduduk Punia 6.884 orang, penduduk yang bekerja sebanyak 2.749 orang $(39,93 \%)$ dan sebanyak $4.135(60,07 \%)$ tidak bekerja. Jumlah penduduk yang bekerja disektor perdagangan berjumlah 255 orang dan 65 orang bekerja pada bidang kuliner. Adapun distribusi penduduk yang bekerja pada bidang kuliner berdasarkan pada tempat tinggalnya (lingkungan) dapat dilihat pada tabel 1 berikut.

Tabel 1

Penduduk Kelurahan Punia Yang Bekerja Pada Bidang Kuliner

\begin{tabular}{|l|c|}
\hline \multicolumn{1}{|c|}{ Lingkungan } & $\begin{array}{c}\text { Bekerja Pada Bidang Kuliner } \\
\text { (Orang) }\end{array}$ \\
\hline Karang Kelayu & 17 \\
\hline Karang Timbal & 4 \\
\hline Punia Jamak & 12 \\
\hline Punia Karang Kateng & 12 \\
\hline Punia Saba & 20 \\
\hline Total & 65 \\
\hline
\end{tabular}

Sumber: Data Sekunder (diolah)

Menjadi pedagang kuliner bagi para pedagang kuliner di Kelurahan Punia merupakan salah satu pilihan pekerjaan yang dipandang sebagai pekerjaan yang relatif mudah untuk dilakukan, hal ini disebabkan karena profesi menjadi pedagang kuliner merupakan profesi yang didapatkan dari orang tuanya ( turun temurun) dan pendapatan yang diperoleh dari hasil dari pekerjaan ini relatif cukup untuk membiayai kehidupannya. Selanjutnya, walaupun makanan yang mereka jual diminati oleh pembeli yang berdampak pada tingkat penjualan dan pendapatan mereka yang cukup, tetapi dilain sisi pedagang belum memperhatikan kualitas makanan dan minuman yang mereka jual bila dilihat berdasarkan pada aspek higiene dan sanitasinya sehingga apabila hal ini dibiarkan berlanjut, dalam jangka panjang dapat menggangu omzet penjualan mereka, karena konsumen 
lambat laun akan mengetahuinya dan konsumen tidak akan membeli produk yang ditawarkan. Hal ini disebabkan karena makanan yang tidak higiene dan sanitasi yang buruk akan dapat menimbulkan berbagai penyakit seperti : diare, mual, muntah-muntah, nyeri perut, demam dan nyeri kepala.

Berdasarkan pada paparan diatas maka diperlukan untuk melakukan pengabdian masyarakat terkait dengan Peningkatan Pengetahuan Tentang Higiene dan Sanitasi Serta Implementasinya Pada Pedagang Kuliner Kaki Lima, Pada Pusat Kuliner di Kelurahan Punia Kota Mataram

\section{METODE KEGIATAN}

Metode pemecahan masalah yang digunakan dalam kegiatan ini adalah:

a. Observasi

Kegiatan observasi dilakukan kepada sasaran target untuk memastikan permasalahan yang dihadapi oleh sasaran target. Sasaran target adalah pedagang kuliner di Kelurahan Punia Kota Mataram yang merupakan salah satu pusat kuliner di Kota Mataram. Observasi lapangan ini dilakukan pada akhir bulan Pebruari 2020. Agar akurasi hasil observasi menjadi lebih akurat maka tim pengabdian melakukan konfirmasi kepada beberapa pedagang kuliner dan kepada istri kepala lingkungan terkait dengan temuan dari tim pengabdian mengenai permasalahan yang dihadapi oleh pedagang kuliner.

b. Penyuluhan

Tujuan dari penyuluhan yang dilakukan adalah untuk meningkatkan pengetahuan pedagang kuliner mengenai higiene dan sanitasi serta diharapkan pedagang kuliner dapat mengimplementasikan pengetahuannya dalam proses produksi hingga dalam proses penjualan produknya. Adapun materi yang disampaikan adalah bagaimana membuat produk yang berkualitas, pentingnya higiene dan sanitasi, dampak kualitas produk terhadap kesejahteraan pedagang, kontribusi 
pedagang terhadap kesejahteraan masyarakat kemudian dilanjutkan dengan diskusi serta pembentukkan tim kelompok /petugas yang akan melakukan monitoring dan evaluasi terhadap penerapan prinsip- prinsip higine dan sanitasi dalam proses produksi yang dilakukan oleh pedagang

C. Pendampingan

Tim pengabdian mengusulkan untuk membuat kelompok monitoring yang beranggotakan pedagang kuliner yang mempunyai pengalaman yang relatif lebih banyak dibandingkan dengan anggota yang lainnya . Kelompok monitoring ini bertugas untuk mengingatkan pedagang kuliner untuk menerapkan prinsip - prinsip higiene dan sanitasi dalam proses produksinya hingga tahap penjualan makanan dan minuma. Untuk memastikan bahwa tim monitoring ini berjalan sesuai dengan tugasnya dan untuk untuk memotivasi pedagang untuk dapat saling mengingatkan dan mengimplementasikan pentingnya prinsip - prinsip higiene dan sanitasi dalam pemilihan bahan baku untuk pengolahan makanan, proses produksi hingga pada pejualan produk yang dihasilkan, sehingga diharapkan produk yang dijual sesuai dengan Undang- Undang No 32 tentang kesehatan maka dilakukan pendampingan selama dua minggu oleh tim pengabdian.

\section{PEMBAHASAN}

1. Hasil dan Pembahasan Observasi

Pelaksanaan kegiatan pengabdian kepada masyarakat ini diawali dengan kegiatan observasi terhadap sasaran target yang dilaksanakan pada akhir bulan oktober 2020. Hasil observasi yang dilakukan oleh Tim di konfirmasi kepada beberapa pedagang kuliner dan kepada istri kepala lingkungan terkait dengan temuan dari tim pengabdian sehingga hasil observasi mempunyai validitas yang tinggi.

Berdasarkan hasil observasi tersebut terindentifikasi permasalahnnya adalah a) Pedagang kuliner melakukan kegiatan 
usahanya secara turun temurun b) Pedagang kuliner tidak memiliki pengetahuan yang cukup mengenai higiene dan sanitasi hal ini terindikasi dari pemilihan bahan baku yang tidak mempertimbangkan kualitas, proses produksi yang dilakukan tanpa mempertimbangkan kebersihan dan penjualan produk belum memenuhi syarat kebersihan yaitu sering makanan yang dijual tidak ditutup sehingga memungkinkan debu untuk masuk pada makanan tersebut disamping itu pengambilan makan tidak menggunakan sendok.

2. Hasil dan Pembahasan Penyuluhan

Jumlah pedagang kuliner yang mengikuti penyuluhan ini berjumlah 20 orang, dimana peserta penyuluhan ini berasal dari RT 01 Karang Kelayu Kelurahan Punia. Adapun lokasi pelaksanaan dari pengabdian ini bertempat di rumah kepala lingkungan Karang Kelayu. Materi penyuluhan yang disampaikan meliputi; bagaimana membuat produk yang berkualitas, pentingnya higiene dan sanitasi, dampak kualitas produk terhadap kesejahteraan pedagang, kontribusi pedagang terhadap kesejahteraan masyarakat kemudian dilanjutkan dengan diskusi serta pembentukkan tim kelompok/petugas yang akan melakukan monitoring dan evaluasi terhadap penerapan prinsip- prinsip higine dan sanitasi dalam proses produksi yang dilakukan oleh pedagang Penyuluhan ini dapat dikatakan berhasil hal ini terlihat dari tingkat kehadiran dan respon peserta dalam kegiatan pengabdian ini sebagai berikut:

a) Jumlah peserta sesuai dengan target yang ditetapkan yaitu sebanyak 20 orang

b) Keaktifan peserta saat pelatihan cukup tinggi. Hal ini terlihat dari berbagai pertanyaan yang disampaikan terutama mengenai pemilihan bahan baku, penyimpanan bahan baku, proses produksi serta penataan produk pada saat penjualan 
c). Peserta bersedia menularkan pengetahuan yang diperolehnya pada pengrajin yang lain diseputar tempat mereka tinggal

d) Adanya keinginan dari peserta untuk membentuk kelompok/petugas monitoring terhadap proses produksi serta penjualan produk. Hal ini dimaksudkan untuk memberikan masukkan kepada pedagang yang belum mengimplementasikan pengetahuan terkait dengan higiene dan sanitasi untuk mengimplemtasikannya pada proses produksi, penyimpanan barang serta pejualan produk dengan cara-cara yang sangat mengedukasi

Sedangkan faktor penghambat dari pelaksanaan kegiatan pengabdian ini adalah tujuh puluh lima persen peserta yang teribat dalam pengabdian ini mempunyai waktu kerja yang relatif panjang sehingga tim pengabdian harus menyesuaikan waktu penyuluhan dengan waktu dari para peserta dan disepakati waktu penyuluhan malam hari. Waktu penyuluhan malam hari ini dirasakan cukup melelahkan bagi peserta karena mereka sudah bekerja sepanjang hari sehingga mereka sulit berkonsentrasi pada materi penyuluhan. Untuk mengatasi hal tersebut penyuluhan dilkasanakan secara perlahan- lahan sehingga dapat dipastikan bahwa peserta memahami materi penyuluhan dengan baik. 


\section{Jurnal ABDIMAS INDEPENDEN}

Vol. 2, No. 2, November 2021
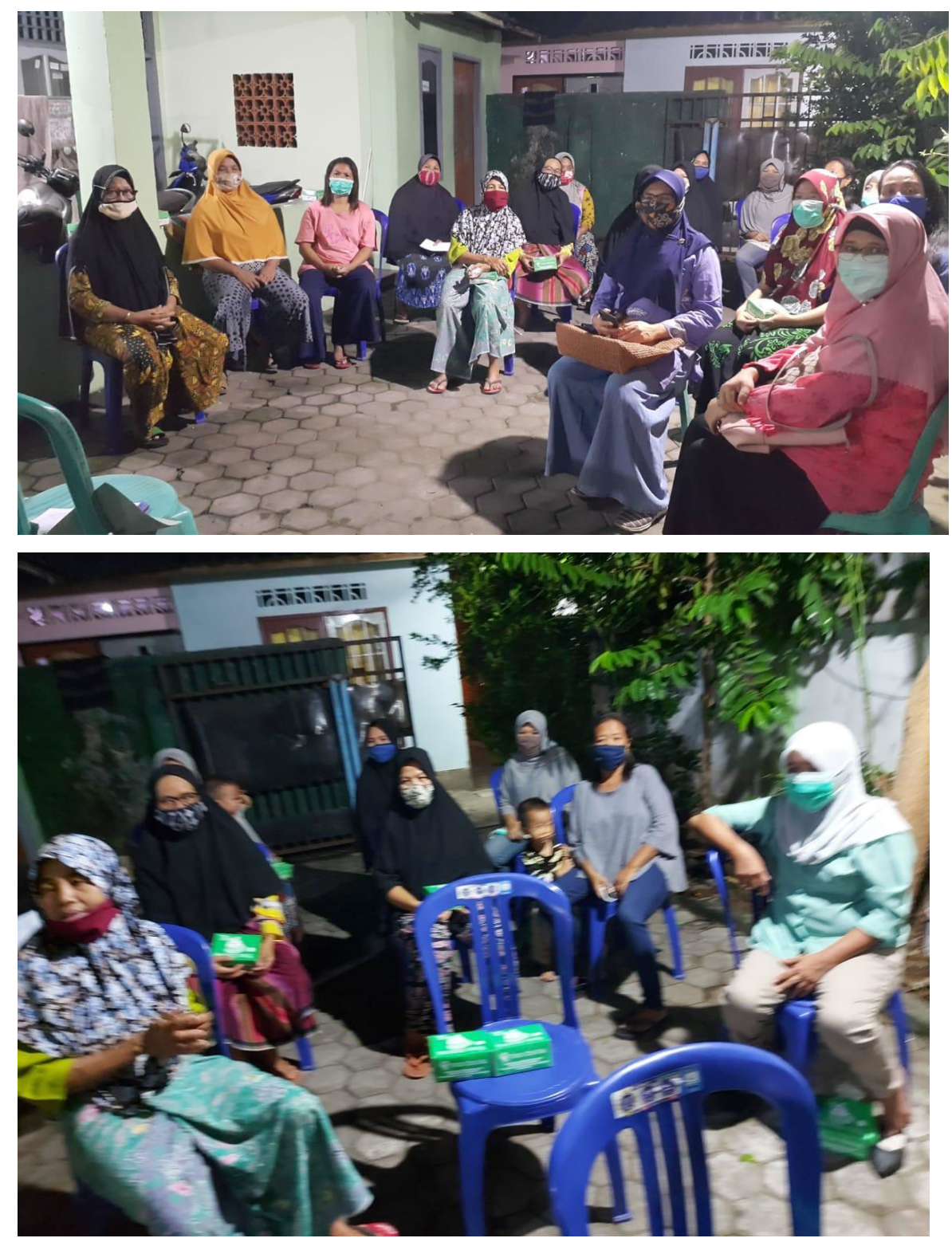

Gambar 1: Suasana Pada Saat Penyuluhan

3. Hasil dan Pembahasan Pendampingan

$$
\text { Pendampingan dilakukan selama dua minggu untuk }
$$

memastikan berjalannya kelompok monitoring yang beranggotakan pedagang kuliner yang mempunyai pengalaman yang lebih banyak dari anggota lainnya, yang bertugas untuk mengingatkan pedagang kuliner untuk menerapkan prinsip - prinsip higiene dan sanitasi dalam proses produksinya hingga tahap penjualan makanan dan 
minuma. Disamping memastikan berjalannya kelompok monitoring ini, pendampingan juga dimaksudkan untuk memotivasi pedagang untuk dapat selalu saling mengingatkan/mengimplementasikan pentingnya prinsip-prinsip higiene dan sanitasi dalam pemilihan bahan baku untuk pengolahan makanan, proses produksi hingga pada pejualan produk yang dihasilkan sehingga diharapkan produk yang dijual sesuai dengan Undang- Undang No 32 tentang kesehatan.

\section{KESIMPULAN DAN SARAN}

\section{Kesimpulan}

Berdasarkan hasil kegiatan pelaksanaan pengabdian masyarakat terkit dengan Peningkatan Peningkatan Pengetahuan Tentang Higiene Dan Sanitasi serta Implementasinya Pada Pedagang Kuliner Kaki Lima, Pada Pusat Kuliner Di Kelurahan Punia Kota Mataram dapat ditarik kesimpulan sebagai berikut:

1. Penyelenggaraan pelatihan tidak mengalami hambatan, hal ini disebabkan adanya kerjasama yang sangat baik antara tim penyuluh dengan ketua RT 01 Karang Kelayu sehingga peserta dapat mengikuti acara pelatihan tepat waktu.

2. Kehadiran peserta cukup tinggi yakni $100 \%$ dari target yang ditetapkan.

3. Keaktifan peserta saat pelatihan cukup tinggi. Hal ini terlihat dari berbagai pertanyaan yang disampaikan terutama mengenai pengertian higiene dan sanitasi serta penerapannya dalam proses produksi.

4. Peserta bersedia menularkan pengetahuan yang diperolehnya pada pedagang diseputar tempat mereka tinggal.

5. Adanya keinginan dari peserta untuk membentuk kelompok/ petugas monitoring terhadap proses produksi dan penjualan terkait dengan higiene dan sanitasi 


\section{Jurnal ABDIMAS INDEPENDEN}

Vol. 2, No. 2, November 2021

\section{Saran}

Berdasarkan hasil dari kegiatan pengabdian ini, maka saran yang diberikan adalah:

1. Perlu dilakukan penguatan kapasitas terkait dengan higiene dan sanitasi sehingga produk yang dihasilkan berkualitas

2. Perlu dilakukan evaluasi dan monitoring yang dilakukan oleh petugas yang berpengalaman yang ditunjuk oleh para pedagang kuliner dan berasal dari para pedagang kuliner itu sendiri, untuk memastikan proses produksi dan penjualan hasil produk telah memenuhi standar higiene dan sanitasi

3. Instansi terkait (Dinas Koperasi dan Usaha Kecil, Dinas Kesehatan) harus melakukan pembinaan dan pendampingan terhadap pedagang kuliner sehingga produk yang dihasilkan oleh pedagang kuliner telah memenuhi persyaratan higiene dan sanitasi dan diharapkan pada akhirnya dapat meningkatkan omzet penjualan

\section{UCAPAN TERIMA KASIH}

Pada kesempatan ini Tim Pengabdian kepada Masyarakat menyampaikan ucapan terima kasih yang sebesar-besarnya atas bantuan dan dukungan dari berbagai pihak sehingga pengabdian ini dapat berlangsung dengan baik. Terima kasih diucapkan kepada:

1. Rektor Universitas Mataram

2. Dekan Fakultas Ekonomi dan Bisnis Universitas Mataram

3. Ketua Lembaga Pengabdian Kepada Masyarakat Universitas Mataram

4. Ketua BP2EB Fakultas Ekonomi dan Bisnis Universitas Mataram

5. Ketua RT 01 Karang Kelayu dan pedagang kuliner yang menjadi subjek pengabdian ini. 


\section{DAFTAR PUSTAKA}

Alamsyah, Yuyun. (2008).Bisnis Kuliner Tradisional. Jakarta: PT Elex Media Komputindo

Anwar,D. (1990) Kamus Besar Bahasa Indonesia. Surabaya : Amelia

Arsyad Lincolin, Ekonomi Pembangunan Edisi 5, STIM YKPN Yogyakarta, 2010

Depkes RI (1992) Undang-Undang no. 23 tahun 1992 Tentang Kesehatan 